Communications may be submitted in English or in German. Further details regarding the submission of communications can be found in the "Notice to Authors" reproduced in the January issue of the journal. Copies thereof may be obtained from the editorial office upon request.

\section{Light-Sensitive Molecular Building Blocks with Electron Transfer Activity: Synthesis and Properties of a Photochemically Switchable, Dicyanovinyl- Substituted Furan **}

\section{By Jörg Daub, * Josef Salbeck, Thomas Knöchel, Christian Fischer, Horst Kunkely, and Knut M. Rapp}

Photochromic groups have the potential for serving as an "antenna" function; that is, they can be used to trigger photoinduced reactions in which the molecular structure, electronic structure, and physical characteristics of a substrate are reversibly altered. Such reactions are particularly easily demonstrated in the case of photochromic groups bound to polymers. ${ }^{[1-3]}$ Multifunctional compounds with photochromic characteristics can thus behave as photochemically activated switches and sensors, the precise characteristics of which depend upon the nature of the functional groups. The magnitude of such an effect is governed by the extent to which the various groups interact.

We have previously demonstrated a significant influence of substituents upon the switchable photochromic system dihydroazulene $1 \rightleftarrows$ vinylheptafulvene 2 , a system activated by visible light. ${ }^{[4]}$ These studies have now been extended to include oligofunctional compounds in an attempt to examine the mutual influences exerted by a photochemically

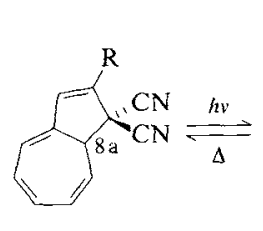

1

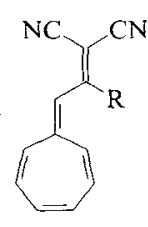

2

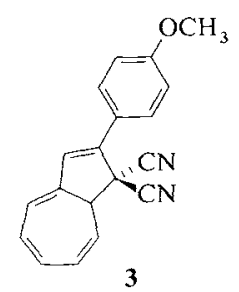

3<smiles>[R]=Cc1ccc(C=C(C#N)C#N)o1</smiles>

["] Prof. Dr. J. Daub, Dr. J. Salbeck, Dr. T. Knöchel, Dipl.-Chem. C. Fischer, Dr. H. Kunkely

Institut für Organische Chemie der Universität

Universitätstrasse 31, D-8400 Regensburg (FRG)

Dr. K. M. Rapp

Südzucker A.G. Mannheim/Ochsenfurt, Zentrallaboratorium D-6718 Grünstadt (FRG)

[**] This work was supported by the Volkswagen-Stifung, the Bundesminister für Forschung und Technologie, and the Deutsche Forschungsgemeinschaft. switchable substrate and various covalent or non-covalent functional groups ${ }^{[5 a]}$ or macromolecules. ${ }^{[5 b, 6]}$ Here we report results on the light-sensitive and electron-transfer-active reactant pair $\mathbf{1} \mathbf{a} \rightleftarrows \mathbf{2 a}$. In these compounds the photochromic dihydroazulene unit is attached covalently to a dicyanovinyl substituent, which provides the electron-transfer capability. The connecting link is a 2,5-furandiyl residue. That the latter is capable of serving as an efficient transmitter of substituent effects is further demonstrated by the electrontransfer chemistry of 4.

In contrast to $3{ }^{[4]]}$ room-temperature irradiation with visible light of a solution containing 1 a does not lead directly to observable photochromism. The only immediate change is the appearance of a weak absorption band in the electronic spectrum at $550 \mathrm{~nm}$, suggesting that a small amount of 1 a has been converted to $\mathbf{2 a}$. However, if irradiation is conducted at $-50^{\circ} \mathrm{C}$ the originally orange solution changes to blue. The UV/VIS spectrum reveals a decrease in absorption at $440 \mathrm{~nm}$ and an intensification of the new band at $548 \mathrm{~nm}$, which can be assigned unambiguously to the vinylheptafulvene $\mathbf{2 a}$ (Fig. 1). These observations indicate that in the case of furan-substituted compounds of the type $\mathbf{1} \rightleftarrows 2$, particularly if there are $-\mathrm{M}$ substituents in the furan ring, the reverse thermal reaction $2 \rightarrow 1$ is so rapid that room-temperature photochromism is prevented.

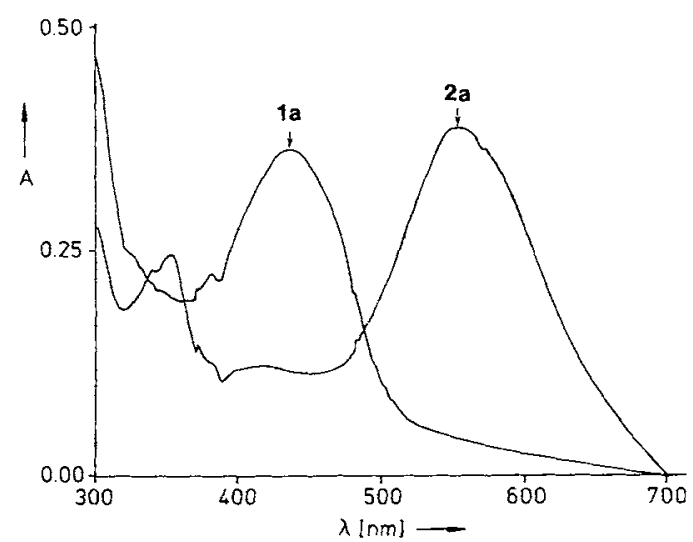

Fig. 1. Electronic spectrum of the photochromic system $1 \mathrm{a} \rightleftarrows 2 \mathrm{a}$ at $-50^{\circ} \mathrm{C}$ in ethanol. Irradiation: ethanol film, mercury lamp (Osram HBO 100 W/2); Balzers filter K2 $(420-480 \mathrm{~nm}) ; 30 \mathrm{~s}$. Isosbestic points at 335,362 , and $468 \mathrm{~nm}$. Ordinate: arbitrary units.

The reductive portion of the cyclic voltammogram for $\mathbf{1}$ a [in acetonitrile, tetrabutylammonium hexafluorophosphate as supporting electrolyte, vs. ferrocene (FOC)] reveals a signal $\left(E_{\mathrm{p}, \mathrm{irr}}\right)$ at $-1185 \mathrm{mV}$ that clearly indicates irreversible formation of the radical anion $1 \mathbf{a}^{\cdot} \ominus$. The model compound 4, containing two dicyanovinyl groups, behaves differently; both cyclic voltammetry and UV/VIS spectroelectrochemistry suggest reversible conversion of $\mathbf{4}$ (yellow) into the radical anion $4^{\cdot \ominus}$ (blue, $E_{1,2}=-890 \mathrm{mV}$ vs. FOC) and the dianion $4^{2 \ominus}$ (orange, $E_{1 / 2}=-1240 \mathrm{mV}$ vs. FOC) (Fig. 2). The locations of the most intensive absorption bands are: for the neutral compound $4,392 \mathrm{~nm}$ with a shoulder at $409 \mathrm{~nm}$; for the radical anion $4^{\ominus}, 599 \mathrm{~nm}$; and for the dianion $4^{2 \ominus}$, $493 \mathrm{~nm}$ with a shoulder at $467 \mathrm{~nm}$. In the case of the benzoid analogue of 4 [i.e., a benzene ring bearing $p$-bis(dicyanovinyl) groups], both the radical anion and the dianion rapidly undergo further chemical reactions. ${ }^{[7,8]}$ 

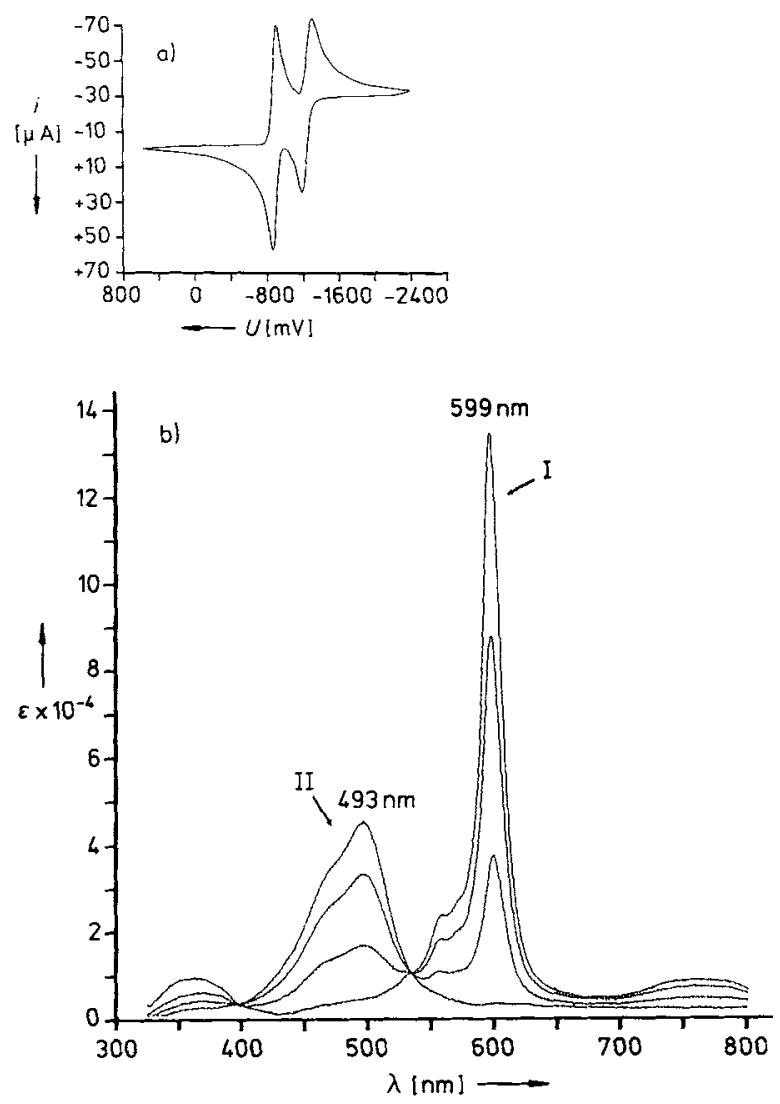

Fig. 2. (a) Cyclic voltammogram of the model compound 4 in acetonitrile $\left(c=4 \times 10^{-3} \mathrm{M}\right), 0.1 \mathrm{M}$ tetrabutylammonium hexafluorophosphate as supporting electrolyte, potential data vs. ferrocene (FOC). (b) UV/VIS spectroelectrochemistry of 4 in acetonitrile $\left(c=1 \times 10^{-3} \mathrm{M}\right)$. Measurement conditions for curve I: $-1000 \mathrm{mV}$ vs. FOC (formation of $4^{\ominus}$ ); for curve II: $-1400 \mathrm{mV}$ vs. FOC (formation of $4^{2 \theta}$ ). Isosbestic points at 391 and $530 \mathrm{~nm}$.

Photoelectrochemical experiments were carried out in a specially constructed cell ${ }^{[9]}$ that permits irradiation of a solution of $\mathbf{1} \mathbf{a}$ in acetonitrile with simultaneous detection of

$$
\begin{aligned}
& { }_{\mathrm{NC}}^{\mathrm{NC}}-\mathrm{C}=\mathrm{HC}-\mathrm{O}_{\mathrm{O}}-\mathrm{CH}=\mathrm{C}_{-}^{-}{ }_{\mathrm{CN}}^{\mathrm{CN}} \\
& \mathrm{e}^{\ominus} \hat{\|}+\mathrm{e}^{\ominus} \quad E_{1 / 2}=-890 \mathrm{mV} \\
& \mathrm{NC}_{\widehat{\ominus}} \mathrm{C}-\mathrm{HC}={ }_{\mathrm{O}}=\mathrm{CH}-\mathrm{C} \cdot{ }_{\mathrm{CN}}^{\mathrm{CN}} \quad 4^{\bullet \bullet} \\
& e^{\ominus} \mid \hat{l}+e^{\ominus} \quad E_{1 / 2}=-1240 \mathrm{mV} \\
& \mathrm{NC}^{\ominus े} \mathrm{C}-\mathrm{HC}={ }_{\mathrm{O}}=\mathrm{CH}-\mathrm{C}^{-}{ }_{\mathrm{CN}}^{\mathrm{CN}} \quad 4^{2 \theta}
\end{aligned}
$$

current flow. Figure 3 shows the results in the form of a current/time curve for a sample subjected to a series of light pulses (5-sec duration) from a high-pressure xenon-mercury lamp (XBO). Current was measured as a function of the pulse train, maintaining a working potential of $-1050 \mathrm{mV}$ (vs. FOC). At this potential $\mathbf{1} \mathbf{a}$ is inert, but $\mathbf{2} \mathbf{a}$ is reduced to the radical anion $2 \mathbf{a}^{\bullet}$, as is apparent from a comparison with the half-cell potential $E_{1 / 2}$ for $4 / 4^{\bullet} \ominus$. The intensity of the electrochemical signals diminishes with time, an indication that under these reaction conditions the radical anion $2 \mathbf{a}^{\circ} \theta$

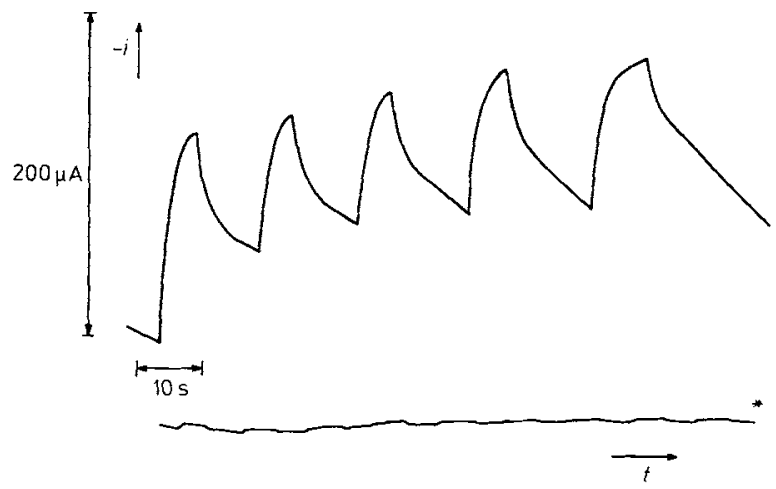

Fig. 3. Upper curve: photochemical switching effect upon irradiation of 19 in acetonitrile $\left(c=1 \times 10^{-3} \mathrm{M}\right)$ at a potential of $-1050 \mathrm{MV}$ vs. FOC. Lower curve: no switching effect at a potential of $-800 \mathrm{mV}$ vs. FOC.

is subject to further transformations. Apparently the heptafulvene fragment in $2 \mathbf{a}^{\ominus} \ominus$ lowers its chemical stability.

The observed results may be interpreted with respect to the electron-transfer characteristics of compounds 1 a and 2 a as follows: the bis(dicyanovinyl)furan derivative $\mathbf{2} \mathbf{a}$ that arises from light-induced ring opening of $\mathbf{1}$ a is more readily reduced than 1 a itself. Therefore, establishment of an appropriate electrochemical potential permits detection of a cathode current. ${ }^{[10]}$

Compound 1 a was synthesized in part from substances of plant origin and in part from petrochemical reagents. The<smiles>O=CCCCCCCCCC=O</smiles>

electron-transfer portions of $\mathbf{1} \mathbf{a}$ and $\mathbf{2} \mathbf{a}$ were derived from D-fructose by way of the intermediate 5-(hydroxymethyl)furfural $5 .^{[1]}$ Oxidation of 5 produced the dialdehyde 6 (barium manganate, 1,2-dichloroethane). ${ }^{[12]}$ Knoevenagel condensation of 6 to 4 was carried out as a solid-state reaction (trituration of 6 in a mortar with malononitrile and neutral aluminum oxide, $70 \%$ yield). ${ }^{[13]}[8+2]$ cycloaddition with 8-methoxyheptafulvene ${ }^{[15]}$ and subsequent elimination of methanol $\left(\mathrm{P}_{2} \mathrm{O}_{5}\right)$ produced the photochromic dihydroazulene $1 \mathrm{a}$ in good yield. . $^{[4,16\}}$

Received: June 14, 1989 supplemented version: August 4, 1989 [Z 3395 IE German version: Angew. Chem. 101 (1989) 1541

CAS Registry numbers:

$1,123077-83-8 ; 2,123077-84-9 ; 3,88694-82-0$.

[1] Recent review of photochromic compounds: H. Dürr, Angew. Chem. 101 (1989) 427; Angew. Chem. Int. Ed. Engl. 28 (1989) 413.

[2] F. Ciardelli, C. Carlini, R. Solaro, A. Altomare, O. Pieroni, J. L. Houben A. Fissi, Pure Appl. Chem. 56 (1984) 329.

[3I I. Cabrera, F. Shyartsman, O. Veinberg, V. A. Krongauz, Science (Washington, D.C.) $226(1984) 341$.

[4] a) J. Daub, T. Knöchel, A. Mannschreck, Angew. Chem. 96 (1984) 980 Angew. Chem. Int. Ed. Engl. 23 (1984) 960; b) J. Daub, S. Gierisch, U. Klement, T. Knöchel, G. Maas, U. Seitz, Chem. Ber. 119 (1986) 2631 ; c) S Gierisch, J. Daub, ibid. 122 (1989) 69; d) S. Gierisch, W. Bauer, T. Burgemeister, J. Daub, ibid., im Druck.

[5] a) Excerpts from J. Daub, J. Achatz, S. Gierisch. T. Knöche!, J. Salbeck. Seventh International Conference on Photochemical Conversion and Storage of Solar Energy. Evanston, IL (USA) 1988, Abstr. S. 60; b) J. Daub, Naurod-Treffen "Optische und elektronische Phänomene in organischen Fesikörpern", Wiesbaden-Naurod, May 1989.

[6] Related studies: J. Anzai, A. Ueno, T. Osa, J. Chem. Soc. Chem. Commun. 1984, 688; H. Tachibana, T. Nakamura, M. Matsumoto, H. Komizu. E. Manda, H. Niino, A. Yabe. Y. Kawabatta, J. Am. Chem. Soc. 111 (1989) 3080 . 
[7] J. Daub, Nachr. Chem. Tech. Lab. 36 (1988) 896.

[8] R. O. Loufty, C. K. Hsiao, B. S. Ong, B. Keoshkerian, Can, J. Chem. 62 (1984) 1877.

[9] J. Salbeck, C. Fischer, unpublished results.

[10] Photochemical production of heptafulvene was demonstrated through cyclic voltammetry studies with a model compound based on 3 , one in which the $-\mathrm{OCH}_{3}$ group was replaced by $-\mathrm{CN}$. The signal obtained prior to irradiation had a peak potential of $-1540 \mathrm{mV} v \mathrm{vs}$. FOC. This may be ascribed to formation of a short-lived radical anion of $3(-C N$ in place of $-\mathrm{OCH}_{3}$ ). Irradiation led to a new signal with a peak potential of $-1235 \mathrm{mV}$ vs. FOC. This signal corresponds to irreversible formation of the radical anion derived from the heptafulvene that results from photochemical ring opening (C. Fischer, unpublished results). Technical diffrculties have so far prevented similar experiments with $1 / 2$.

[11] Cf. H. Schiweck, K. Rapp, M. Vogel, Chem. Ind. (London) 1988, 228.

[12] a) H. Firouzabadi. E. Ghaderi. Tetrahedron Leat. 1978, 839; b) A. F. Oleinik, K. Yu. Novitskii, J. Org. Chem. USSR (Engl. Transl.) 6 (1970) 2643; T. El Hajj, A. Masroua, J.-C. Martin. G. Descotes, Bull. Soc. Chim. Fr. 1987,855 .

[13] Cf. F. Texier-Boullet, A Foucaud, Tetrahedron Lett. 23 (1982) 4927.

[14] Cf. K. Yu. Novitskii, V. P. Volkov, Yu. K. Yur'ev, Zhur. Ohshch. Khim. 31 (1961) 538 ; Chem. Abstr. 55 (1961) 23485 h.

[15] Synthesis of dihydroazulenes: J. Daub, S. Gierisch, T. Knöchel, E. Salbeck, G. Maas, Z. Naturforsch. B41 (1986) 1151.

[16] Additional spectroscopic and analytical data: $1: m p=172-173^{\circ} \mathrm{C}$; $\mathrm{MS}$ $(70 \mathrm{eV}) ; m / e 322\left(M^{+}, 100 \%\right), 295(M-\mathrm{HCN}, 31 \%) ; \mathrm{IR}(\mathrm{KBr})$ : $\left[\mathrm{cm}^{-1}\right]=2220 ;{ }^{1} \mathrm{H}$ NMR $\left(250 \mathrm{MHz}, \mathrm{CDCl}_{3}\right): \delta=3.8(\mathrm{~m}, 1 \mathrm{H}: 8 \mathrm{a}-\mathrm{H}), 5.8$ (dd. $J=10.6,3.8 \mathrm{~Hz}, 1 \mathrm{H} ; 8-\mathrm{H}), 7.5\left[\mathrm{~s}, 1 \mathrm{H} ; \mathrm{CH}=\mathrm{C}(\mathrm{CN})_{2}\right]$; correct elemental analysis obtained. $\mathbf{- 4}: \mathrm{mp}=195-197^{\circ} \mathrm{C}: \mathrm{IR}(\mathrm{KBr}): \hat{\mathrm{F}}\left[\mathrm{cm}^{-1}\right]=$ $2220 ;{ }^{1} \mathrm{H}$ NMR (250 MHz, [D 6 ] DMSO): $\delta=7.7$ (s, $2 \mathrm{H}$ ) 8.5 (br.s, $2 \mathrm{H}$ ); correct elemental analysis obtained. A $\mathrm{mp}=207-208^{\circ} \mathrm{C}$ has been reported for 4 prepared by a different method [14].

\section{$\left.\left\{\mathrm{Cp}^{\prime}(\mathrm{CO})_{2} \mathrm{Mn}\right\}_{2} \mathrm{PbStBu}\right]^{\ominus}$; Completion of an Isoelectronic Series of Binuclear Complexes Containing Trigonal-Planar Coordinated Main Group Elements **}

\section{By Frank Ettel, G. Huttner, ${ }^{*}$ and Laszlo Zsolnai \\ Dedicated to Professor Margot Becke-Goehring on the occasion of her 75 th birthday}

The relationship between dimetalla-allene systems and "inidene"-complexes ${ }^{[1]}$ was recently demonstrated with the reaction sequence $\mathbf{1} \rightarrow \mathbf{2} \rightarrow 3^{[2.3]}$ for elements of the fifth main group as central atom.

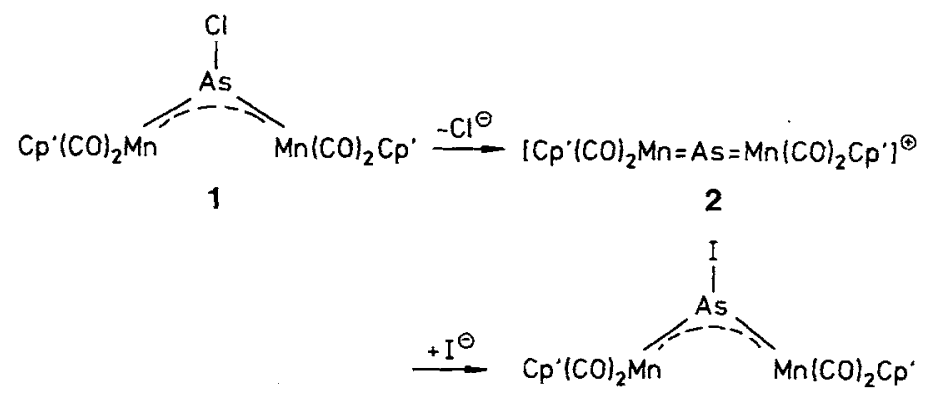

$C p^{\prime}=\mathrm{C}_{5} \mathrm{H}_{4} \mathrm{Me}$

$$
3
$$

Since the bonding pattern found in "inidene" complexes for elements of the fifth main group can also be realized with elements of the sixth main group, e.g. $4,{ }^{[4]}$

$\left\{\left\{\mathrm{Cp}(\mathrm{CO})_{2} \mathrm{Mn}\right\}_{2} \mathrm{SPh}\right\}^{\oplus} \quad 4$

[*] Prof. Dr. G. Huttner, Dipl.-Chem. F. Ettel, Dr. L. Zsolnai Anorganisch-chemisches Institut der Universität Im Neuenheimer Feld 270, D-6900 Heidelberg (FRG)

[**] This work was supported by the Fonds der Chemischen Industrie and by the Deutsche Forschungsgemeinschaft (SFB 247). we were encouraged to check for this bonding pattern also with elements of the fourth main group as bridge ligands by reaction of the corresponding heterocumulenes with Lewis bases.

The heterocumulenes $\left[\mathrm{L}(\mathrm{CO})_{2} \mathrm{Mn}=\mathrm{X}=\mathrm{Mn}(\mathrm{CO})_{2} \mathrm{~L}\right]$ $\left(\mathrm{L}=\mathrm{Cp}, \mathrm{Cp}^{\prime}\right)$ were first described by $E$. Weiss et al. $(\mathrm{X}=\mathrm{Ge})^{[5,6]}$ and $W$. A. Hermann et a]. $(\mathrm{X}=\mathrm{Pb}) .^{[7]}$ In the reaction of the hydrido complex $5^{[8]}$ with $\mathrm{PbCl}_{2}$ or $\mathrm{GeCl}_{4}$ we have now found a preparatively productive novel entry to these complexes, which serve as the necessary starting materials in this study.

The $\mathrm{Pb}$-derivative 6 reacts spontaneously with alkali-metal thiolates to give anionic adducts (bathochromic shift of

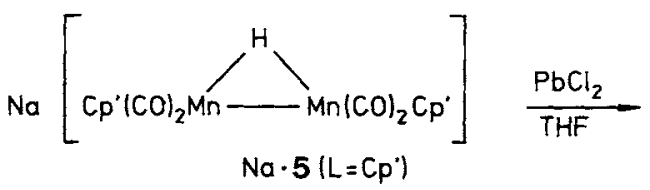

$\left[\mathrm{Cp}(\mathrm{CO})_{2} \mathrm{Mn}=\mathrm{Pb}=\mathrm{Mn}(\mathrm{CO})_{2} \mathrm{Cp}^{\prime}\right]$

6

the $v_{c o}$ vibrations by ca. $30 \mathrm{~cm}^{-1}$ ). By addition of cryptands to the reddish-brown solutions, the corresponding salts can be obtained in crystalline form.

$6 \frac{1 . \text { LiStBu }}{2 .[2.1 .1] \mathrm{crypt}}$

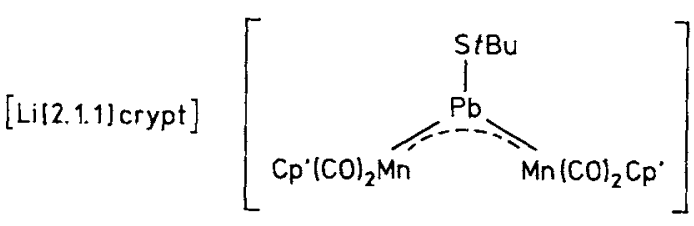

$$
[\text { Lil2.1.11 crypt }] \cdot 7
$$

For the derivative 7 , the expected trigonal-planar coordination of the lead atom could be confirmed by an X-ray structure analysis ${ }^{[9]}$ (Fig. 1).

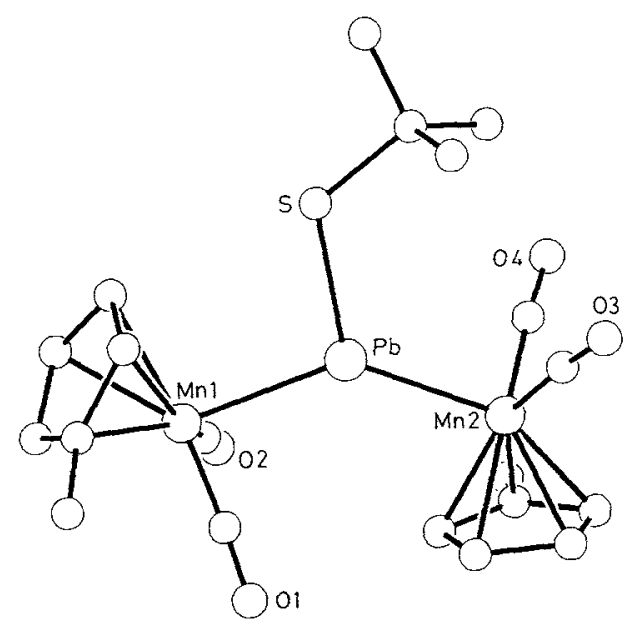

Fig. 1. Structure of 7 in the crystaj. 